\title{
EFEKTIFITAS PEMBELAJARAN MATEMATIKA MELALU PENDEKATAN PROBLEM POSSING SETTING KOOPERATIF PADA SISWA KELAS V SD INPRES BATANGKALUKU KEC. SOMBA OPU KAB. GOWA
}

\author{
Dyandra Pramudita, Baharullah, Mukhlis. \\ Pendidikan Guru Sekolah Dasar, Fakultas Keguruan dan Ilmu Pendidikan, \\ Universitas Muhammadiyah Makassar \\ Iqramsyar34@gmail.com
}

\begin{abstract}
ABSTRAK
Masalah utama dalam penelitian ini yaitu apakah pembelajaran matematika efektif melalui penerapan pendekatan Problem Posing Setting Kooperatif pada siswa Kelas V SD Inpres Batangkaluku Kecamatan Somba Opu Kabupten Gowa. Penelitian ini bertujuan untuk mengetahui efektivitas pembelajaran matematika melalui penerapan pendekatan Problem Posing setting Kooperatif pada siswa Kelas V SD Inpres Batangkaluku Kecamatan Somba Opu Kabupten Gowa. Jenis Penelitian ini adalah penelitian pra eksperimen yang hanya melibatkan satu kelas dan dilaksanakan sebanyak empat kali pertemuan. Satuan eksperiment di lakukan secara acak (random). Desain penelitian ini adalah the one group pretest-posttest design. Prosedur penelitian ini meliputi memberikan tes awal(pretest) kepada kelas yang terpilih, melakukan kegiatan pembelajaran dengan menggunakan pendekatan Problem Posing setting Kooperatif, setelah pembelajaran diberikan lagi tes akhir (posttest), dan melakukan analisis data pretest dan posttest yang telah dikumpulkan. Satuan eksperimen dalam penelitian ini adalah siswa Kelas V SD Inpres Batangkaluku Kecamatan Somba Opu Kabupten Gowa .Teknik pengumpulan data yang digunakan adalah tes hasil belajar yang diberikan kepada siswa, lembar observasi untuk mengamati aktivitas siswa selama proses pembelajaran, lembar observasi aktivitas guru untuk mengamati keterlaksanaan pembelajaran oleh guru dalam mengelola pembelajaran sesuai dengan RPP dan angket respon siswa untuk mengetahui tanggapan dan saran siswa terhadap pelaksanaan pembelajaran matematika melalui penerapan pendekatan Problem Posing setting Kooperatif. Hasil penelitian menunjukkan bahwa: (1) skor rata-rata 83 dari skor ideal 100, skor terendah 53 dan skor tertinggi 100 dengan standar deviasi 69,85 dan tercapai tuntas klasikal. (2) Persentase rata-rata aktivitas siswa mencapai 72,9\%. (3) Aktivitas guru berada pada kategori baik dengan skor rata-rata 3,6. (4) Respon positif siswa mencapai 92\%. Berdasarkan hasil penelitian tersebut di atas, dapat disimpulkan bahwa pembelajaran matematika efektif melalui penerapan pendekatan Problem Posing setting Kooperatif pada siswa Kelas V SD Inpres Batangkaluku Kecamatan Somba Opu Kabupten Gowa.
\end{abstract}

Kata kunci: Efektivitas; Problem Posing Setting Kooperatif; Pembelajaran Matematika. 


\section{PENDAHULUAN}

Keberhasilan pembangunan suatu bangsa sangat tergantung pada Sumber Daya Manusia (SDM) sedangkan keberhasilan SDM sangat ditentukan oleh pendidikannya. Hal yang menjadi sorotan pada dunia pendidikan pada dewasa ini adalah rendahnya mutu lulusan pada setiap jenjang pendidikan lebih spesifik pada pembelajaran matematika.

Matematika bagi siswa SD berguna untuk kepentingan hidup dalam lingkungannya, untuk mengembangkan pola pikirnya, dan untuk mempelajari ilmuilmu yang lainnya. Kegunaan atau manfaat matematika bagi para siswa SD adalah sesuatu yang jelas dan tidak perlu dipersoalkan lagi, lebih-lebih pada era pengembangan ilmu pengetahuan dan teknologi. Namun pelajaran matematika hingga saat ini belum menjadi pelajaran yang difavoritkan dan dianggap sulit sehingga dalam proses pembelajaran siswa kurang aktif dan sangat berdampak pada rendahnya prestasi belajar siswa. Hal ini juga terjadi pada siswa SD Inpres Batang Kaluku Kecamatan Somba Opu Kabupaten Gowa.

Berdasarkan observasi awal data yang diperoleh dari guru kelas di SD Inpres Batang Kaluku mengatakan bahwa rata-rata hasil belajar saat ulangan tengah semester (Maret tahun ajaran 2015/2016) pada mata pelajaran matematika masih rendah, yaitu 64 berada di bawah standar kriteria Ketuntasan Minimal (KKM) yang ditetapkan di sekolah tersebut yaitu 68. Selain hasil belajar matematika siswa yang tidak tuntas, guru juga kesulitan dalam mengajar, karena siswa rata-rata beranggapan bahwa pelajaran matematika merupakan pelajaran yang sulit dipahami, yang membuat siswa cenderung bersifat pasif menunggu sajian guru dari pada mencari dan menemukann sendiri pengetahuan, keterampilan, dan sikap yang mereka butuhkan (observasi, 16 April 2016).

Untuk mengatasi masalah tersebut maka dibutuhkan suatu pendekatan pembelajaran yang baru sehingga proses pembelajaran dapat berjalan efektif yaitu pendekatan problem posing setting kooperatif, dimana pendekatan pembelajaran yang telah dikembangkan dan diyakini dapat meningkatkan aktivitas, kesenangan dan prestasi siswa dalam belajar matematika, juga dapat memotivasi siswa untuk berpikir kritis dan kreatif. Guru jarang memberikan kesempatan kepada siswa untuk membuat soal dan menyelesaikannya sendiri. Oleh karna itu, pendekatan Problem Posing setting kooperatif diharapkan siswa lebih bersemangat, sehingga mampu belajar sesuai 
dengan tingkat berfikirnya. Pengetahuan siswa dengan pendekatan ini, bisa dikembangkan dari yang sederhana hingga pada pengetahuan yang kompleks. Siswa diberi kesempatan dalam membuat soal baru dan menyelesaikannya sendiri tanpa bimbingan guru sehingga siswa tersebut terbiasa dalam mengerjakan soal yang ada pada buku tanpa dijelaskan kembali dan siswa juga tidak selalu bergantung pada contoh soal yang diberikan oleh guru, maka dari itu pembelajaran Problem Posing setting kooperatif digunakan dalam pembelajaran di kelas.

Berdasarkan uraian di atas rumusan masalah dalam penelitian ini adalah: Apakah Pembelajaran Matematika efektif melalui penerapan Pendekatan Problem Posing setting kooperatif pada siswa kelas V SD Inpres Batang Kaluku Kecamatan Somba Opu Kabupaten Gowa?". (1) Tujuan penelitian ini adalah mengetahui: Ketuntasan hasil belajar matematika siswa dengan pendekatan problem possing setting kooperatif. (2) Aktivitas siswa dalam proses pembelajaran matematika dengan pendekatan problem possing setting kooperatif. (3) Aktivitas guru dalam mengelola kelas dengan pendekatan problem possing setting kooperatif. (4) Respon siswa terhadap proses pembelajaran dengan pendekatan problem possing setting kooperatif.

\section{Pengertian Belajar}

Wingkel (Susanto, 2013:4) mengemukakan pengertian belajar merupakan suatu aktivitas mental yang berlangsung dalam interaksi aktif antara subjek dengan lingkungannya, dan menghasilkan perubaha-perubahan dalam pengetahuan, pemahaman, keterampilan, dan nilai sikap yang bersifat menetap. Perubahanperubahan itu dapat berupa sesuatu yang baru dan segera nampak dalam perilaku nyata".

Sedangkan menurut Hamalik (Susanto, 2013:3) belajar adalah memodifikasi atau memperteguh perilaku melalui pengalaman (learning is defined as the modificator or strengthening of behavior though experiencing). Menurut pengertian ini, belajar merupakan suatu proses, suatu kegiatan, dan bukan merupakan suatu hasil atau tujuan. Dengan demikian, belajar itu bukan sekedar mengingat atau menghafal saja, namun lebih luas dan itu merupakan mengalami”.

Dari beberapa pengertian belajar diatas, dapat simpulkan bahwa belajar adalah suatu aktivitas yang dilakukan seseorang dengan sengaja, dalam keadaan sadar untuk memperoleh suatu konsep, pemahaman, atau pengetahuan baru sehingga 
memungkinkan seseorang terjadinya perubahan perilaku yang relatif tetap baik dalam berpikir, merasa, maupun dalam bertindak.

\section{Efektivitas Pembelajaran}

Efektivitas sendiri diartikan keadaan berpengaruh, hal berkesan, keberhasilan usaha atau tindakan. Efektivitas berarti berusaha untuk dapat mencapai sasaran yang telah ditetapkan sesuai dengan kebutuhan yang diperlukan, sesuai pula dengan rencana, baik dalam penggunaan data, sarana, maupun waktu.

Pembelajaran merupakan perpaduan dari dua kata belajar dan mengajar. Dimana, aktivitas belajar secara metodologi cenderung lebih dominan pada siswa, sementara mengajar secara instruksional dilakukan oleh guru, dimana peran guru lebih ditekankan kepada bagaimana merancang atau mengaransemen berbagai sumber dan fasilitas untuk digunakan siswa dalam mempelajari sesuatu. Menurut Undang-Undang Sistem Pendidikan Nasional No.20 Tahun 2003, pembelajaran diartikan sebagai proses pada suatu lingkungan belajar.

Efektivitas pembelajaran merupakan tolok ukur keberhasilan guru mengelolah kelas, efektivitas yang dimaksud akan tergambar melalui hasil belajar siswa. Adapun indikator efektivitas dalam penelitian ini adalah sebagai berikut:

a. Ketuntasan Hasil Belajar Matematika Siswa

b. Aktivitas siswa dalam proses pembelajaran

c. Aktivitas guru

d. Respon siswa terhadap pembelajaran

\section{Hakikat Pembelajaran Matematika}

Kata metamatika berasal dari bahasa latin, manthanein atau mantema yang berarti "belajar atau hal yang dipelajari". Sedangkan dalam bahasa Belanda, matematika disebut wiskunde atau ilmu pasti, yang kesemuanya berkaitan dengan penalaran.

Pembelajaran matematika adalah suatu proses belajar mengajar yang dibangun oleh guru untuk mengembangkan kreativitas berpikir sisiwa yang dapat meningkatkan kemampuan berpikir siswa, serta dapat meningkatkan kemampuan mengkonstruksi pengetahuan baru sehingga sebagai upaya meningkatkan penguasaan yang baik terhadap materi matematika.

Mata pelajaran matematika dapat dipandang sebagai pelajaran yang ampuh untuk mencapai disiplin mental. Namun matematika berdasarkan teori daya, lebih 
banyak menekankan pada penyajian soal yang sulit. Hal ini bertujuan agar siswa terbiasa berpikir. Kemampuan berpikir ini pada akhirnya dapat ditransfer dalam memecahkan masalah kehidupan, baik bidang sosial, politik, dan sebagainya.

\section{Pendekatan Problem Posing}

Problem posing adalah istilah dalam bahasa inggris yang terdiri dari dua kata yaitu "problem" yang artinya masalah dan "posing" berasal dari kata "pose" artinya mengajukan atau membentuk. Problem posing merupakan pembelajaran dimana siswa diminta untuk mengajukan masalah (soal) berdasarkan situasi tertentu. Setiawan (Wiranata, 2012) mengatakan pembentukan soal mencakup dua kegiatan, yaitu:

a. Pembentukan soal baru atau pembetukan soal dari situasi atau dari pengalaman siswa.

b. Pembentukan soal dari soal yang sudah ada.

Suryanto (Widi, 2015) mengartikan problem posing yaitu "perumusan soal dengan bahasa yang baku/standar atau perumusan kembali soal yang ada dengan beberapa perubahan agar sederhana dan dapat dikuasai”. Sama halnya dengan As'ari (Widi, 2015) mengartikan problem posing yaitu "dengan pembentukan soal, merumuskan soal atau, menyusun soal".

Berdasarkan uraian diatas, dapat simpulkan bahwa problem posing merupakan model pembelajaran dimana siswa ditugaskan untuk menyusun masalah atau soal sesuai dengan pemahaman masing-masing siswa.

\section{METODE PENELITIAN}

Jenis penelitian ini adalah penelitian pra eksperimen yang hanya melibatkan satu kelompok sebagai kelas eksperimen atau kelas uji coba dengan tujuan untuk mengetahui efektivitas model pembelajaran pendekatan Problem Posing setting kooperatif dalam pembelajaran matematika. Desain penelitian yang digunakan adalah One Group Pretest Posttes Design. Penelitian ini hanya melibatkan satu kelas yaitu kelas eksperimen yang dilaksanakan tanpa adanya kelas pembanding.

Populasi dari penelitian ini adalah Siswa Kelas V SD Inpres Batang Kaluku Kecamatan Somba Opu Kabupaten Gowa tahun ajaran 2016/2017 yang terdiri dari 2 kelas dengan jumlah siswa kelas V.a sebanyak 34 orang dan kelas V.b sejumlah 31 orang. Tehnik pengambilan sampel yang digunakan adalah simple random sampling yaitu dari 2 kelas diambil satu kelas secara acak untuk dijadikan sampel dengan 
pertimbangan kelas homogen yang berkedudukan sama tanpa memperhatikan strata. Dimana kelas V.a diambil sebagai sampel.

\section{HASIL PENELITIAN DAN PEMBAHASAN}

Dalam penelitian ini diperoleh beberapa data berupa pretest yang diberikan sebelum diberikan perlakuan untuk mengukur sejauh mana tingkat kemampuan siswa dalam pembelajaran matematika. Kemudian data hasil belajar siswa setelah diberikan perlakuan (posttest), data hasil pengamatan aktivitas siswa, data tentang kemampuan guru dalam mengola pembelajaran, data tentang respon siswa terhadap proses pembelajaran yang terjadi. Adapun hasil analisis masing-masing data tersebut adalah sebagai berikut :

\section{Hasil Analisis Statistik Deskriptif}

a. Hasil Analisis Pretest

Dari hasil analisis deskriptif sebagaimana yang terlampir pada lampiran D, maka statistik skor hasil belajar siswa pada kelas V SD Inpres Batangkaluku Kecamatan Somba Opu Kabupaten Gowa sebelum dilaksanakan perlakuan (pretest) untuk materi matriks disajikan dalam Tabel 4.1 berikut.

Tabel 1. Deskripsi Pretest Skor Hasil Belajar Matematika Siswa Kelas V SD Inpres Batangkaluku Kecamatan Somba Opu Kabupaten Gowa

\begin{tabular}{cc}
\hline Statistik & Nilai \\
\hline Ukuran Sampel & 34 \\
Skor Ideal & 100 \\
Skor Rata-rata & 65.35 \\
Skor Tertinggi & 100 \\
Skor Terendah & 40 \\
Rentang Skor & 60 \\
Standar Deviasi & 16.86 \\
Jika skor hasil belajar matematika siswa & sebelum perlakuan (pretest) \\
mpokkan kedalam lima kategori, maka diperoleh distribusi frekuensi dan skor \\
mase yang ditunjukkan pada tabel 2. berikut.
\end{tabular}


Tabel 2. Distribusi Pretest frekuensi dan Persentase Skor Hasil Belajar Matematika Siswa Kelas V SD Inpres Batangkaluku Kecamatan Somba Opu Kabupaten Gowa

\begin{tabular}{cccc}
\hline Skor & Kategori & Frekuensi & Persentase (\%) \\
\hline $\mathbf{0} \leq x<\mathbf{5 7}$ & Sangat rendah & 12 & 35.29 \\
$\mathbf{5 8} \leq x<\mathbf{6 7}$ & Rendah & 9 & 26.47 \\
$\mathbf{6 8} \leq x<\mathbf{7 7}$ & Sedang & 3 & 8.82 \\
$\mathbf{7 8} \leq x<\mathbf{8 7}$ & Tinggi & 6 & 17.65 \\
$\mathbf{8 8} \leq x \leq$ & Sangat tinggi & 4 & 11.77 \\
$\mathbf{1 0 0}$ & & $\mathbf{3 4}$ & $\mathbf{1 0 0}$ \\
\hline \multicolumn{3}{c}{ Jumlah }
\end{tabular}

Berdasarkan tabel 2. terlihat bahwa persentase skor hasil belajar matematika siswa sebelum diterapkan pendekatan Problem Posing setting kooperatif yakni dari 34 siswa terdapat 12 siswa atau 35.29 yang masuk kategori sangat rendah, 9 siswa atau 26.47 yang masuk kategori rendah, 3 siswa atau 8.82 yang masuk kategori sedang.

Kemudian untuk melihat persentase ketuntasan hasil belajar matematika siswa sebelum perlakuan (pretest) dapat dilihat pada tabel 4.3 berikut.

Tabel 3. Kriteria Ketuntasan Hasil Belajar Matematika Siswa kelas V SD Inpres Batangkaluku Kecamatan Somba Opu kabupaten Gowa

\begin{tabular}{cccc}
\hline Skor & Kriteria & Frekuensi & $\begin{array}{c}\text { Persentase } \\
(\%)\end{array}$ \\
\hline $0 \leq x<67$ & Tidak & 21 & 61,76 \\
& Tuntas & & \\
\multirow{2}{*}{$68 \leq x \leq 100$} & Tuntas & 13 & 38.24 \\
Jumlah & & 34 & 100 \\
\hline
\end{tabular}

Berdasarkan tabel 3. sebelum perlakuan (pretest) dapat digambarkan bahwa dari 34 siswa terdapat 121 siswa atau 61.76 yang masuk kategori tidak tuntas dan 13 siswa atau 38,24 termasuk kategori tuntas.

b. Hasil Analisis Posttest 
Statistik skor hasil belajar siswa pada kelas V SD Inpres Batangkaluku Kecamatan Somba Opu Kabupaten Gowa setelah dilaksanakan perlakuan (posttest) pada pokok bahasan matriks disajikan dalam tabel 4.4 brikut

Tabel 4. Statistik Posttest Skor Hasil Belajar Matematika Siswa Kelas V SD Inpres Batangkaluku Kecamatan Somba Opu Kabupaten Gowa

\begin{tabular}{cc}
\hline Statistik & Nilai \\
\hline Ukuran Sampel & 34 \\
Skor Ideal & 100 \\
Skor Rata-rata & 83 \\
Skor Tertinggi & 100 \\
Skor Terendah & 53 \\
Rentang Skor & 47 \\
Standar Deviasi & 9.85 \\
\hline
\end{tabular}

Berdasarka tabel 4. menunjukkan bahwa rata-rata skor hasil belajar matematika siswa yang diajar dengan menggunakan Pendekatan Problem Posing setting kooperatif adalah 83 dari skor ideal 100. Skor tertinggi yang dicapai siswa adalah 100 dan skor terendah 53, dengan standar deviasi sebesar 9.85 yang berarti bahwa skor Hasil Belajar Matematika Siswa Kelas V SD Inpres Batangkaluku Kecamatan Somba Opu Kabupaten Gowa pada posttest tersebar dari skor terendah 53 sampai skor tertinggi 100.

Jika skor hasil belajar matematika yang diajar dengan menggunakan pendekatan Problem Posing setting kooperatif dikelompokkan kedalam lima kategori, maka diperoleh distribusi skor frekuensi dan persentase yang ditunjukkan pada Tabel 4.5 berikut.

Tabel 5. Distribusi Posttest frekuensi dan Persentase Skor Hasil Belajar Matematika Siswa Kelas V SD Inpres Batangkaluku Kecamatan Somba Opu Kabupaten Gowa

\begin{tabular}{cccc}
\hline Skor & Kategori & Frekuensi & Persentase (\%) \\
\hline $0 \leq x<57$ & Sangat rendah & 1 & 2.94 \\
$58 \leq x<67$ & Rendah & 1 & 2.94 \\
$68 \leq x<77$ & Sedang & 7 & 20.59 \\
\hline
\end{tabular}




\begin{tabular}{cccc}
\hline $78 \leq x<87$ & Tinggi & 17 & 50 \\
$88 \leq x \leq 100$ & Sangat tinggi & 8 & 23.53 \\
Jumlah & 34 & 100 \\
\hline
\end{tabular}

Berdasarkan tabel 5. di atas, dapat disimpulkan bahwa persentase skor hasil belajar matematika siswa setelah diterapkan pendekatan Problem Posing setting kooperatif yakni dari 34 siswa terdapat 1 siswa atau 2,94 yang masuk kategori sangat rendah, 1 siswa atau 2.94 yang termasuk kategori rendah, 7 siswa atau 20.59 yang masuk kategori sedang, 17 siswa atau 50\% yang masuk kategori tinggi, dan 8 orang atau 23,53 masuk dalam kategori sangat tinggi.

Kemudian untuk melihat persentase ketuntasan hasil belajar matematika siswa setelah perlakuan (posttest) dengan menerapkan pendekatan Problem Posing setting kooperatif dapat dilihat pada Tabel 4.6 berikut.

Tabel 6. Kriteria Ketuntasan Hasil Belajar Matematika Siswa Kelas V SD Inpres Batangkaluku Kecamatan Somba Opu Kabupaten Gowa

\begin{tabular}{cccc}
\hline Skor & Kriteria & Frekuensi & $\begin{array}{c}\text { Persentase } \\
(\%)\end{array}$ \\
\hline $0 \leq \times<67$ & Tidak & 2 & 5,88 \\
& Tuntas & & \\
$68 \leq x \leq 100$ & Tuntas & 32 & 94,12 \\
& & 34 & 100 \\
\hline
\end{tabular}

Berdasarkan tabel 6. setelah perlakuan (posttest) dengan pendekatan Problem Posing setting kooperatif dapat digambarkan bahwa yang telah mencapai ketuntasan hasil belajar 32 orang dari jumlah keseluruhan 34 orang dengan persentase 94,12 sedangkan yang tidak mencapai ketuntasan belajar sebanyak 2 orang dari jumlah keseluruhan 34 orang dengan persentase 5,88.

1) Komparasi Tingkat Hasil Belajar Siswa

Dari pembahasan di atas, apabila disajikan dalam tabel akan terlihat jelas perbedaan hasil belajar siswa sebelum dilaksanakan perlakuan (pretest) dan setelah dilaksanakan perlakuan (posttest) yang ditunjukkan pada Tabel 4.7 berikut.

Tabel 7. Statistik Hasil Belajar Matematika Siswa Pretest dan Posttest 


\begin{tabular}{ccc}
\hline Statistik & Nilai Pretest & Nilai Posttest \\
\hline Ukuran Sampel & 34 & 34 \\
Skor Ideal & 100 & 100 \\
Skor Rata-rata & 65.35 & 83 \\
Skor Tertinggi & 100 & 100 \\
Skor Terendah & 40 & 53 \\
Rentang Skor & 60 & 47 \\
Standar Deviasi & 16.86 & 9.85 \\
\hline
\end{tabular}

Dari tabel 7. di atas digambarkan bahwa skor rata-rata siswa setelah diterapkan pendekatan Problem Posing setting kooperatif lebih tinggi yaitu 83 dengan rentang skor 47 dibanding dengan pretest atau sebelum dilaksanakan perlakuan yaitu 65.35 dengan rentang skor 60.

2) Aktivitas Siswa

Hasil pengamatan aktivitas siswa dengan menerapkan pendekatan Problem Posing setting kooperatif selama 4 kali pertemuan dinyatakan dalam persentase. Berdasarkan pengamatan aktivitas siswa dapat dilihat bahwa selama kegiatan pembelajaran pendekatan Problem Posing setting kooperatif berlangsung, siswa telah terlibat secara aktif sehingga dominasi guru dalam pembelajaran dapat berkurang. Secara umum, hasil analisis data aktivitas siswa menunjukkan sebagian besar siswa aktif selama pembelajaran berlangsung.

Hasil analisis statistika deskriptif menunujukkan bahwa skor Hasil Belajar Matematika Siswa Kelas V SD Inpres Batangkaluku Kecamatan Somba Opu Kabupaten Gowa sebelum diterapkan pendekatan Problem Posing setting kooperatif berada pada kategori yang sangat rendah. Hal ini terlihat dari skor rata-rata hasil belajar matematika siswa sebesar 65.35 dan dari 34 siswa yang memiliki hasil belajar matematika siswa dalam kategori rendah.

Sementara itu skor Hasil Belajar Matematika Siswa Kelas V SD Inpres Batangkaluku Kecamatan Somba Opu Kabupaten Gowa setelah diterapkan pendekatan Problem Posing setting kooperatif terjadi peningkatan yang signifikan yaitu berada pada kategori tinggi. Hal ini terlihat dari skor rata-rata sebesar 83 dan dari 34 siswa, 2,94\% siswa yang memiliki hasil belajar matematika dalam kategori sangat rendah, 
2,94\% dalam kategori rendah, 20,59\% dalam kategori sedang, 50\% dalam kategori tinggi, dan 23.53\% dalam kategori sangat tinggi dengan standar deviasi 9.85 .

Berdasarkan Kriteria Ketuntasan Minimal (KKM) pada SD Inpres Batangkaluku Kecamatan Somba Opu Kabupaten Gowa, yaitu siswa dikatakan tuntas belajar jika hasil belajarnya telah mencapai skor 68 dan mencapai ketuntasan klasikal, jika 75\% siswa mencapai skor 68, maka siswa yang mencapai ketuntasan belajar adalah sebanyak 34 orang dari jumlah keseluruhan 34 orang dengan persentase $75 \%$. Hal ini berarti bahwa pendekatan Problem Posing setting kooperatif dapat membantu siswa untuk mencapai ketuntasan secara klasikal.

Berdasarkan hasil analisis deskriptif yang telah diuraikan, dapat disimpulkan bahwa hasil belajar matematika siswa setelah diterapkan pendekatan Problem Posing setting kooperatif tuntas secara klasikal, aktivitas siswa yang berkaitan dengan kegiatan pembelajaran mengalami peningkatan, kemampuan guru dalam mengelola pembelajaran mencapai kriteria baik, serta respon siswa terhadap model pembelajaran Problem Posing positif. Dengan demikian, dapat disimpulkan bahwa pembelajaran matematika efektif melalui pendekatan Problem Posing setting kooperatif pada siswa kelas V SD Inpres Batangkaluku Kecamatan Somba Opu Kabupaten Gowa.

\section{SIMPULAN DAN SARAN}

Berdasarkan hasil penelitian dan pembahasan yang telah dikemukakan pada BAB IV maka dapat disimpulkan sebagai berikut: (1) Hasil belajar matematika yang dicapai kelas siswa Kelas V SD Inpres Batangkaluku Kecamatan Somba Opu Kabaupaten Gowa sebelum perlakuan (pretest) termasuk dalam kategori sangat rendah dengan skor rata-rata 65.35 dari skor ideal 100. Skor tinggi yang dicapai siswa adalah 100, dan skor terendah 40, dengan stndar deviasi sebesar 16.86. Hal ini juga menunjukkan bahwa yang tidak mencapai ketuntasan belajar sebanyak 34 orang dari jumlah keseluruhan dengan persentase 100\%. (2) Rata-rata persentase frekuensi aktivitas siswa yang berkaitan dengan kegiatan pembelajaran mengalami peningkatan dari pertemuan I sampai dengan pertemuan IV. Sedangkan persentase frekuensi aktivitas siswa yang tidak berkaitan dengan kegiatan pembelajaran, menurun dari pertemuan I sampai dengan pertemuan IV. Berdasarkan kriteria aktivitas siswa pada BAB III dapat disimpulkan bahwa siswa aktif selama pembelajaran matematika melalui pendekatan 
Problem Posing setting kooperatif. (3) Dari keseluruhan aspek kemampuan guru dalam mengelola pembelajaran diperoleh nilai rata-rata 3,63 dengan kriteria sangat baik. Sesuai dengan kriteria keefektifan maka kemapuan guru dalam mengelola pembelajaran melalui pendekatan Problem Posing setting kooperatif dikatakan efektif. (4) Pendekatan Problem Posing setting kooperatif pada siswa Kelas V SD Inpres Batangkaluku Kecamatan Somba Opu Kabaupaten Gowa mendapat respon yang positif dengan rata-rata persentasi siswa yang memberi respon positif adalah 92\%. (5) Hasil belajar matematika yang dicapai siswa Kelas V SD Inpres Batangkaluku Kecamatan Somba Opu Kabaupaten Gowa setelah perlakuan (posttest) dengan pendekatan Problem Posing setting kooperatif termasuk dalam kategori tinggi dengan skor ratarata 83 dari skor ideal 100. Skor tertinggi yang dicapai siswa adalah 100 dan skor terendah 53, dengan standar deviasi sebesar 9.85. Hal ini juga menunjukkan bahwa setelah perlakuan (posttest) dengan pendekatan Problem Posing setting kooperatif dapat digambarkan bahwa yang telah mencapai ketuntasan hasil belajar 32 orang dari jumlah keseluruhan 34 orang dengan persentase 94.12 sedangkan yang tidak mencapai ketuntasan belajar sebanyak 2 orang dengan persentase 5.88 berdasarkan kriteria ketuntasan hasil belajar yang telah dikemukakan pada BAB III dapat disimpulkan bahwa ketuntasan hasil belajar secara klasikal telah tercapai.

Saran yang dapat diberikan: (1) Guru matematika sebaiknya kreatif dalam menciptakan suasana kelas agar siswa tidak cepat bosan dan tegang dalam belajar serta lebih termotivasi untuk memperhatikan apa yang diajarkan. (2) Dalam pemberian soal guru matematika harus pintar dalam memilih soal-soal mana yang mampu di kerjakan siswa sesuai materi yang telah di berikan. (3) Kepada guru matematika khususnya agar dapat mencoba menerapkan pendekatan Problem Posing setting kooperatif dalam proses belajar mengajar sebagai salah satu upaya meningkatkan hasil belajar siswa serta aktivitas siswa dalam pembelajaran. Sebagai tindak lanjut penerapan, pada saat proses pembelajaran diharapkan guru untuk lebih mengawasi dan mengontrol serta membimbing siswa dalam belajar mandiri. 


\section{DAFTAR PUSTAKA}

Asrori, Mohammad. 2009. Psikologi Pembelajaran. Bandung: CV. Wacana Prima.

Aqib, Zainal. 2014. Model-model, Media, dan Strategi Pembelajaran Kontekstual (INOVATIF). Bandung: Yrama Widya.

Brickman, P., "Effects of Inquiry-Based Learning on Students' Science Literacy Skills and Confidence", International Journal for The Scholarship of Teaching and Learning. Vol. 3 (2), 2009.

Borg, W. R. \& Gall, M. D. 1983. Educational Research. Fourth edition. NewYork: Longman Inc.

Dimyati dan Mudjiono. 2009. Belajar dan Pembelajaran. Jakarta: PT. Rineka Cipta

Depertemen Pendidikan Nasional. 2008. Pengembangan Lember Kerja Siswa. Jakarta: Depertemen Pendidikan Nasional.

Hartono, Rudi. 2014. Ragam Model Mengajar yang Mudah Diterima Murid. Jogjakarta: DIVA Press.

Hussain, A., dkk., "Physics Teaching Methods: Scientific Inquiry vs Traditional Lecture”, International Journal of Humanities and Social Learning. Vol. 1 (19), 2011.

Kunandar. 2013. Penilaian Autentik. Jakarta: PT RajaGrafindo Persada.

Kemendiknas. 2007. Permendiknas Nomor 41 Tahun 2007 tentang Standar Proses Pendidikan Dasar dan Menengah. Jakarta.

Nurhadi dkk. 2004. Pembelajaran Kontekstual. Malang: Univessitas Negeri Malang

Purwanto. 2013. Evaluasi Hasil Belajar. Yogyakarta: Pustaka Pelajar.

Putra, Sitiatava Rizema. 2013. Desain Belajar Mengajar Kreatif Berbasis Sains. Jogjakarta: DIVA Press.

Rusman. 2012. Belajar dan Pembelajaran Berbasis Komputer. Bandung: ALFABETA.

Sanjaya, Wina. 2008. Strategi Pembelajaran Berorientasi Standar Proses Pendidikan. Jakarta: Kencana Prenada Media Group.

Samsudi. 2009. Disain Penelitian Pendidikan. Semarang: Unnes Press.

Trianto. 2011. Model Pembelajaran Terpadu. Jakarta: Bumi Aksara.

Trianto. 2013. Mendesain Model Pembelajaran Inovatif-Progresif. Surabaya: Kencana Prenada Media Group. 